\title{
«Los vírgenes esposos del Persiles»: el episodio de Renato y Eusebia
}

\author{
JuAn RAMÓn MuÑoz SÁNCHEZ*
}

El Persiles (1617) es un libro excelente ${ }^{1}$. Es un universo en total madurez que acaso se resiente tan solo por la falta de una última revisión. Es la cima, junto

* Universidad Autónoma de Madrid.

1. Los trabajos de Persiles y Sigismunda es, posiblemente, el texto más controvertido de la producción literaria de Cervantes. Situado en la corriente vanguardista de la prosa de ficción europea del siglo XVII, que había hallado en la Historia etiópica de Heliodoro, al ser considerada como una variante de la épica heroica, solo que amorosa y en prosa, el modelo clásico a emular, el Persiles contribuye a la conformación de la novela moderna desde el género bizantino o la novela barroca de amor y aventuras. Obtuvo un éxito inmediato de ventas, con un total de siete ediciones en el mismo año, 1617, en que salió listo de las prensas. Una notoriedad que se mantuvo intacta, con algún que otro altibajo, durante el siglo XVIII, no solo porque alcanzó otras siete ediciones, sino sobre todo porque se le rindió un caluroso homenaje, hasta el punto de que el primer biógrafo de Cervantes, don Gregorio de Mayans y Siscar, lo ubicó al lado del Quijote, e incluso llegó a sostener que le era superior en la invención (véase Antonio Rey Hazas y Juan R. Muñoz SÁnchez, El nacimiento del cervantismo. Cervantes y el "Quijote» en el siglo XVIII, Madrid, Verbum, 2006, pp. 46-48, 177-178 y 192-197). Fue con el advenimiento, ya en el siglo XIX, de la estética realista y de la crítica positivista cuando el Persiles cayó en desgracia. Censurado y postergado casi hasta el olvido, no pasó de ser entendido como un ensueño inverosímil y romántico de su autor en las postrimerías de su vida. Ha sido el siglo XX, en su segunda mitad, no sin reservas y luego de la crisis del realismo y el auge de la prosa de fícción idealista, el que lentamente ha vuelto a situar el Persiles en el lugar que se merece, gracias a una proliferación de estudios críticos y ediciones modernas: JoAquín CASALDUERO, Sentido y forma de "Los trabajos de Persiles y Sigismunda», Madrid, Gredos, 1975; Antonio Vilanova, «El peregrino andante en el Persiles de Cervantes», Erasmo y Cervantes, Barcelona, Lumen, 1989, pp. 326-409; AlBAN K. Forcione, Cervantes, Aristotle and the «Persiles», Princeton, Princeton University Press, 1970, y Cervantes' Christian Romance: A Study of «Persiles y Sigismunda», Princeton, Princeton University Press, 1972; JUAN Bautista Avalle-Arce, «Los trabajos de Persiles y Sigismunda», Suma cervantina, J. B. Avalle-Arce y E. C. Riley (eds.), London, Tamesis Books, 1973, pp. 199-212, y «Conocimiento y vida en Cervantes», Nuevos deslindes cervantinos, Barcelona, Ariel, 1975, pp. 17-72, sobre todo pp. 58 y ss.; Diana de Armas Wilson, Allegories of Love: Cervantes' "Persiles and Sigismunda», Princeton, Princeton University Press, 1991; S. HARrISON, La composición de «Los trabajos de Persiles y Sigis- 
con la Segunda parte del Quijote, solo que desde una perspectiva creadora diferente, del estilo cervantino, del uso de la expresión verbal o del discurso en una determinada organización de conjunto. Es decir, si entendemos el estilo como una manera de pensar, de ver el mundo, de formar una obra, entonces ya no atañe en exclusividad al léxico o la sintaxis o a procedimientos estilísticos, sino que es también el modo en el que se disponen y despliegan tanto en la superficie lineal del texto como en sus más cavernosas profundidades las diferentes categorías sintácticas y estrategias narrativas que lo conforman ${ }^{2}$. Y es en este sentido en el que el estilo del Persiles, y por ello el Persiles mismo, es igual de fascinante que de soberbio.

\section{LA ESTRUCTURA DEL PERSILES: EL PRECEPTO DE LA VARIEDAD EN LA UNIDAD}

En su postrera obra el genial alcalaíno fundió armoniosamente la épica clásica, que se había puesto de moda con la exhumación y difusión de la tan celebrada prosa épica amorosa del elegante Heliodoro ${ }^{3}$, con la tradición de la novela corta, sirviendo la primera de hilo conductor y haciendo las veces de soporte estructural de la segunda ${ }^{4}$. De modo que en la línea argumental central, a contra-

munda», Madrid, Pliegos, 1993; Maurice Molho, «Preface» a su traducción del Persiles al francés, París, José Corti, 1994, pp. 7-69; Isabel Lozano Renieblas, Cervantes y el mundo del «Persiles», Alcalá de Henares, C.E.C., 1998; M. a AlBerta SACCHEtTi, Cervantes" "Los trabajos de Persiles y Sigismunda». A Study of Genre, London, Tamesis, 2001; Lectures d'une oeuvre. Los trabajos de Persiles y Sigismunda de Cervantes, JeAn-Pierre SÁnchez (coord.), Nantes, Editions du Temps, 2003; Peregrinamente peregrinos. Actas del V Congreso Internacional de la Asociación de Cervantistas, AliciA Villar Lecumberri (coord.), Alcalá de Henares, 2004; Michael Nerlich, El «Persiles» descodificado, o la «Divina Comedia» de Cervantes, trad. de Jesús Munárriz, Madrid, Hiperión, 2005. Quisiéramos dejar constancia, para cerrar este sumario repaso, del hecho de que para algunos de los escritores más relevantes de la literatura española actual el Persiles es, dicho con suma cautela, la mejor obra de Cervantes, como son los casos del poeta catalán Pere GiMferrer (véase El Cultural del periódico El Mundo, 25-11-2004, pp. 8-11, especialmente p. 10) y del novelista madrileño JAVIER MARÍAS (así lo manifiesta en su novela Tu rostro mañana 1. Fiebre y lanza, Madrid, Alfaguara, 2002, pp. 422-423).

2. «Una telaraña, una pauta a la vez sensorial y lógica, una trama elegante y fecunda: eso es el estilo, ese es el fundamento del arte de escribir», según opinaba Robert Louis Stevenson (citado por JUAN Antonio Molina Foix en la introducción a R. L. Stevenson, El extraño caso del doctor Jekill y Mr. Hyde y otros relatos de terror, Madrid, Valdemar, 2006, pp. 9-24, en concreto nota 7 de la p. 14. Véase, además, Umberto Eco, «Sobre el estilo», en Sobre literatura, trad. de Helena Lozano Miralles, Madrid, Debolsillo, Madrid, 2005, pp. 171-188).

3. Véase sobre la novela bizantina EMILIO CARILlA, «La novela bizantina en España», Revista de Filología Hispánica, XLIX, 1966, pp. 275-287; Miguel Ángel TeIJeIro Fuentes, La novela bizantina. Apuntes para una revisión del género, Cáceres, Universidad de Extremadura, 1987; ANA LuISA BAQUERO ESCUDERO, «La novela griega: proyección de un género en la narrativa española», Rilce, VI, 1990, pp. 19-45; JAVIER GonZÁleZ Rovira, La novela bizantina de la Edad de Oro, Madrid, Gredos, 1996; CARLos García GuAL, «Sobre las novelas antiguas y las de nuestro Siglo de Oro», Edad de Oro, XXIV, 2005, pp. 93-105.

4. Véase Ángel García Galiano, «Estructura especular y marco narrativo en el Persiles», Anales Cervantinos, XXXIII, 1995-1997, pp. 177-195; JuAN RAMÓN MuÑoz SÁNCHEZ, «Tradición e inno- 
pelo de lo que había hecho en el Quijote, donde todo se resuelve a un nivel meramente humano, aún persiste la visión de la vida como una totalidad densamente cargada de sentido inmanente, puesto que hay una cierta comprensión entre los héroes y la divinidad, sólo que esta relación transcendental, que es la que propicia la acción heroica, está cristianizada o se adecua a los valores del cristianismo que permite, en su humanismo, una importante libertad de actuación al héroe, en el sentido en el que Dios dispone y el hombre actúa ${ }^{5}$. En el punto y hora en que el texto se reviste con los ropajes de un género elevado como la épica cobra una dimensión ejemplar, cuyos pilares no son otros que valores cristianos tales como la virtud, la caridad, el sufrimiento estoico de los trabajos, el perdón de las ofensas, la castidad, la fidelidad amorosa y el dominio de las pasiones. Por su parte, las novelas cortas, interpoladas en forma de episodios verdaderos y en diferentes grados de solapamiento, pertenecen a las distintas modalidades que ofrecía la prosa de ficción áurea, por lo que se ajustan a sus características respectivas, mas participando, en estrecha relación temática, con la peripecia medular, ora en perfecto paralelo, ora en marcado contraste. De modo que se representa, desde un discurso polifónico, el universo todo, lo uno y su contrario, así como los niveles intermedios. La disposición de la trama remeda un laberinto, en perfecta sintonía con el torbellino de pasiones encendidas que lo pueblan, no sólo por la profusión de episodios que interrumpen de continuo el desarrollo de la acción central, retrasando su resolución, sino también y sobre todo por el empleo del arte retórica del ordo artificialis, que provoca la distorsión cronológica, natural o lineal de la historia, por lo que precisa, a la par que camina hacia el desenlace, de distintas analepsis completivas que palien el comienzo in medias res que, además, no se presentan concatenadas temporalmente, sino que son fragmentos discontinuos. Le corresponde al lector, en consecuencia, encajar las diferentes piezas para desenmarañar la historia o fábula, o sea, interpretar los indicios temporales y espaciales, la lógica de las acciones, el trayecto vital de los protagonistas; vincular la trama medular con los episodios; recomponer el orden cronológico de los acontecimientos y notar y apreciar las relaciones sutiles, las delicadas armonías, las simetrías especulares, que van hilvanando unas partes con otras hasta conformar un todo organizado y cohesionado ${ }^{6}$. Pero aún hay más; el genio artístico de Cervantes no podía encapsularse en los preceptos y las normas de la razón poética sin someterlos a la ironía, el humor y el distanciamiento,

vación en el episodio de Ruperta, la "bella matadora" del Persiles», Revista de Filología Española, LXXXVII, 2007, 1, pp. 103-130, y «Ortel Banedre, Luisa y Bartolomé: análisis estructural y temático de un episodio del Persiles», Criticón, 99, 2007, pp. 125-158.

5. «Cervantes se ha propuesto allí [en el Persiles] el arduo problema de mostrar cómo podría también legitimarse a la altura de su arte la idea de un verdadero roman o libro de entretenimiento cristiano» (Francisco Márquez Villanueva, «Cervantes, libertador libertario», Cervantes en letra viva, Barcelona, Reverso, 2005, pp. 23-47, p. 40). Sobre la ideología moral y religiosa del Persiles es imprescindible ahora la consulta del grueso estudio de Michael Nerlich, citado en la nota 1.

6. Véase JuAn RAmón MuÑoz SÁnchez, «Los episodios de Los trabajos de Persiles y Sigismunda», Hesperia, VI, 2003, pp. 147-173. 
que si no los parodian, al menos los ponen en duda o, en su defecto, los rebajan y los templan 7 y todo ese sentido ejemplar y heroico termina por aproximarse a lo humano, en el que el hombre es hijo de sus obras, y su triunfo no consiste sino en vencerse a sí mismo e integrarse en el ciclo de la vida. Pues al fin de cuentas, como escribía Thomas Mann, «en el reino de lo humano, el conquistador más bravo y cumplido ha sido siempre el humor» ${ }^{8}$, y qué mejor ejemplo que Cervantes, que se despide del mundo, en su obra más seria, del modo más bello y sobrecogedor, y con un admirable sentido del humor:

¡Adiós, gracias; adiós, donaires; adiós, regocijados amigos; que yo me voy muriendo, y deseando veros presto contentos en la otra vida!?.

Por lo tanto, en el resultado, en el sentido último, parece que confluyen el Quijote y el Persiles. Ahora bien, cada uno en su propia ley, puesto que los procedimientos narrativos y los caminos recorridos son tan disímiles que se ha podido llegar a decir «que el Persiles empieza en el punto preciso en que acaba el Quijote» ${ }^{10}$.

En lo que sigue, entonces, no hemos impuesto la tarea de mostrar y constatar este hecho, que el Persiles es un claro ejemplo del dominio absoluto del arte de narrar cervantino en todos los órdenes, desde la disposición general de la trama hasta lo incidental o anecdótico, al calor del análisis del libro II, cifrado en el episodio de Renato y Eusebia. Alrededor de este asunto central, sin embargo, tejeremos no poca vainicas temáticas que evidencian la renovación radical que emprende Cervantes de la tradición literaria, al reemplazarla por una realidad atomizada, que le fuerza a regir su arte por el motivo de la variación o de la reescritura.

\section{EL LIBRO II DEL PERSILES: UN AUDAZ EXPERIMENTO}

La madurez literaria de Cervantes, decimos, y su enorme capacidad narrativa hallan su máxima expresión en el Persiles en el libro II. Constructiva y morfo-

7. «Cervantes se distancia de Heliodoro modernizando el género. Para Cervantes, superar el modelo lleva implícito el respeto por el género, pero, al mismo tiempo, al modernizarlo, lo dilata hasta irritar sus leyes sin llegar a quebrantarlas. La proliferación de relatos orales, las técnicas anticipatorias o el distanciamiento respecto a sus personajes son muestras inequívocas de una actitud irónica. Por eso el Persiles es una estilización pero, a pesar de la distancia o la ironía, no llega a ser una parodia» (I. Lozano Renieblas, Cervantes y el mundo del «Persiles», p. 16). Véase A. K. Forcione, Cervantes, Aristotle and the «Persiles», cap. VIII, pp. 257-301.

8. Thomas Mann, «A bordo con Don Quijote», Cervantes, Goethe y Freud, Madrid, Losada, 2004 , pp. 23-82, la cita en la p. 80.

9. Miguel de Cervantes, Los trabajos de Persiles y Sigismunda, F. Sevilla Arroyo y A. Rey HaZAs (eds.), Madrid, Alianza (Obra completa, vol. 18), 1999, p. 21 (siempre citamos el texto por esta edición, por libro, seguido de capítulo y número de página).

10. J. B. Avalle-Arce, «Los trabajos de Persiles y Sigismunda», Suma cervantina, pp. 199-212, la cita en la p. 212. 
lógicamente es el más complejo de la novela ${ }^{11}$, por cuanto Cervantes simultanea concatenadamente dos narraciones: una, la que prosigue linealmente la acción en tiempo presente de la novela, que gira en derredor de la estancia de la comitiva de personajes que encabezan Periandro y Auristela en la isla del rey Policarpo; otra, la extensa relación del héroe sobre sus peripecias marinas, que no sólo sirve para recuperar parte de la prehistoria de la trama, sino que, desde una perspectiva metafictiva, enjuicia críticamente los resortes de la novela griega de amor y aventuras ${ }^{12}$. La primera recae sobre un narrador primario de carácter extradiegético, el mismo que gobierna todo el entramado de la novela en su acción presente, y que permite tanto la entrada de los relatos adventicios como de las analepsis completivas, pero que, en su notoria evolución a lo largo del texto, se diferencia del narrador del libro I en que la omnisciencia neutra que caracterizaba a este deviene ahora en la de un narrador-editor que, con una calculada infidencia autorial que potencia una multiplicidad de niveles de significado, interviene arbitrariamente con todo tipo de digresiones y comentarios sobre la acción contada, incluso para desmentirla ${ }^{13}$. La segunda recae sobre un personaje, Periandro, en funciones de narrador intradiegético puro o paranarrador, que cuenta a un granado número de receptores o paranarratarios, que representan, apoyándose en la recursividad del lenguaje, a los lectores dentro del texto, tanto sus propias aventuras como las de otros personajes con los que se topa en su deambular marinero por los húmedos y fríos caminos de las aguas septentrionales. Los dos planos narrativos, sin embargo, están inspirados en las dos modalidades de la épica antigua, la heroica y en verso y su degradación, la amorosa y en prosa.

La detención de los héroes en un palacio o corte es un motivo habitual de la novela helenística ${ }^{14}$, cuyo máximo exponente en el momento de redacción del Persiles era la Historia etiópica de Heliodoro, pero que proviene, en última instancia, de la épica arcaica de Homero, cifrado en los nuevos aires novelescos que adopta la Odisea, y de ahí a la épica culta, como se registra en El viaje de los Argonautas de Apolonio de Rodas y en la Eneida de Virgilio. De hecho, la estadía de los héroes en los dominios de Policarpo remeda situaciones de la estancia, en la novela de Heliodoro, de Teágenes y Cariclea en el palacio de Ársace en Menfis (libros VII y VIII) y de la de Leucipa y Clitofonte en el de Mélite y Tersandro en Éfeso, en la novela homónima de Aquiles Tacio (libros $\mathrm{V}$-VIII), en especial respecto al cruce de parejas $^{15}$ y por la intermediación de

11. Véase A. Rey y F. Sevilla, «Introducción», en su edición del Persiles, pp. XXVII-XXX.

12. Véase A. K. Forcione, Cervantes, Aristotle and the «Persiles», pp. 187 y ss.; Stanislav Zimic, «El Persiles como crítica de la novela bizantina», Acta Neophilologica, III, 1970, pp. 49-64; RUTH EL SAFFAR, «Periandro: Exemplary Character-Exemplary Narrator», Hispanófila, LXIX, 1980, pp. 9-16.

13. Véase Juan Bautista Avalle-Arce, Las novelas y sus narradores, Alcalá de Henares, C.E.C., 2006, pp. 133-216.

14. Véase I. Lozano Renieblas, Cervantes y el mundo del «Persiles», p. 144.

15. Véase S. ZIMIC, «El amante celestino y los amores entrecruzados en algunas obras cervantinas», Boletín de la Biblioteca Menéndez Pelayo, XL, 1964, pp. 361-387, y «Leucipe y Clitofonte y Clareo y Florisea en el Persiles de Cervantes», Anales Cervantinos, XIII-XIV, 1974-1975, pp. 37-58. 
una hechicera o maga. Mas por encima de estas parece estar pergeñada por la de Eneas en la corte cartaginesa de la reina Dido, en la Eneida (cantos I-IV), como se declara explícitamente en el texto. Si bien no podemos olvidar que en los triunfos deportivos de Periandro en la isla de Policarpo y en el enamoramiento de Sinforosa resuenan ecos de la Odisea, cuando Ulises es recibido y agasajado en la corte de Feacia (cantos V-XII, especialmente V-VII). De todos modos, no se debe ni se puede despreciar la posible influencia de la literatura caballeresca, máxime cuando este módulo narrativo se inserta hasta la médula tanto en la reflexión como en la concepción que Cervantes efectúa sobre la prosa de ficción, pues de alguna manera se refleja en el Persiles, hasta el punto de que el gran cervantista Edward C. Riley ${ }^{16}$ aseguraba que es «una novela bizantina de ambiente contemporáneo y un libro de caballerías actualizado» ${ }^{17}$. La corte ${ }^{18}$, en los libros de caballerías, desempeña un papel fundamental como espacio de reunión de personajes y lugar en el que habitualmente vive la amada; pero es, además, donde acaece el enfrentamiento entre el rey y el caballero, donde se pone a prueba la virtud, la fidelidad y la entereza moral del héroe y donde este, para completar su configuración modélica, ha de saber desenvolverse a las mil maravillas como caballero fino y cortesano. Buena prueba de ello lo son las estancias de Tirante y Amadís en la corte de Constantinopla y la de don Quijote en el palacio de los duques. Lo más significativo del caso es que, de un modo u otro, tanto en la épica como en los libros de caballerías, la parada del héroe - o los héroes, en la bizantina - en un palacio o corte es generadora siempre de conflictos y suscita un enorme interés sentimental. De resultas, la estancia de Periandro y Auristela en el palacio del rey Policarpo se centra casi exclusivamente en el deseo erótico, merced a una maraña de intrigas amorosas en las que se ven envueltos la gran mayoría de los personajes que habitan la corte y que terminan por converger en ellos. Una galería de casos amorosos, en fin, en la que se expresan las más de sus manifestaciones posibles, desde la mesura hasta la locura, y en las que todos sufren y desean y esperan:

Estas revoluciones, trazas y máquinas amorosas andaban en el palacio de Policarpo y en los pechos de los confusos amantes: Auristela celosa, Sinforosa enamorada, Periandro turbado y Arnaldo pertinaz; Mauricio haciendo

16. «Con posterioridad a 1960, el cervantista que mayor influencia ha ejercido sobre la interpretación de Cervantes es, sin duda alguna, Ted Riley» (AnThony Close, La concepción romántica del «Quijote», trad. de GonZalo G. DJemBé, Barcelona, Crítica, 2005, pp. 293-300, la cita es de la p. 293. Véase, también, José Montero Reguera, «Edward C. Riley o el honor del cervantismo», Bulletin of Spanish Studies, LXXXI, 2004, pp. 415-424).

17. Edward C. Riley, Teoría de la novela en Cervantes, trad. de Carlos Sahagún, Madrid, Taurus, 1989 , p. 94.

18. Véase José Amezcua, Libros de caballerías hispánicos, Madrid, Ediciones Alcalá, 1973; Juan Manuel Cacho Blecua, «Amadis»: Heroísmo mítico cortesano, Madrid, Cupsa, 1979; Francisco Márquez Villanueva, «Doncella soy de esta casa y Altisidora me llaman», Trabajos y días cervantinos, Alcalá de Henares, C.E.C., 1995, pp. 299-340, y «Estratigrafía literaria de don Quijote. ¿Un menosprecio de corte?», Cervantes en letra viva, pp. 235-267. 
disinios de volver a su patria contra la voluntad de Transila, que no quería volver a la presencia de gente tan enemiga del buen decoro como la de su tierra; Ladislao, su esposo, no osaba ni quería contradecirla; Antonio, el padre, moría por verse con su hijos y mujer en España, y Rutilio, en Italia, su patria. Todos deseaban, pero a ninguno se le cumplían sus deseos: condición de la naturaleza humana (II, 4, 164-165).

Un conflicto de múltiples ramificaciones del que solo salen airosos aquellos que son capaces de domeñar sus pasiones, de templar el deseo con la razón.

Carlos García Gual, en su importante estudio sobre la novela helenística de amor y aventuras, señalaba que «hay sólo tres condiciones básicas para ser héroe o heroína de novela griega: juventud, excepcional belleza, y fidelidad tenaz al amor» ${ }^{19}$. Y, efectivamente, sobre estos tres pilares esenciales están pergeñados Periandro y Auristela. Sucede, sin embargo, que Cervantes, en esta su épica en prosa, quería que su campeón del trabajado combate amoroso refulgiese asimismo en el fragor de la batalla y la aventura, que fuese tan enamorado como valiente, que participase, en suma, de la grandeza de Ulises y Eneas, de Amadís y de Tirante. Para ello, separa a los dos amantes, de tal forma que la ausencia de la heroína y su búsqueda le permitan al héroe convertirse en el nuevo caballero andante del mar que busca acrecentar su fama como intrépido, esforzado, comedido, liberal, generoso, caritativo y aun temerario, pues, como sostiene don Quijote, «es más fácil venir el pródigo a ser liberal que el avaro, así es más fácil dar el temerario en verdadero valiente que no el cobarde subir a la verdadera valentía ${ }^{20}$. Ahora bien, sus peripecias como capitán corsario ${ }^{21}$ carecen del soporte del narrador extradiegético, puesto que están narradas en primera persona por él mismo, de manera que aquel no respalda su relato, ni siquiera garantiza su veracidad. A fin de cuentas, Ulises y Eneas no solo eran héroes en el sentido recto del término, sino que además eran excelentes oradores, magos de la palabra, reyes del verbo, hasta el punto de suspender y admirar a sus interlocutores, por lo que, y en función de ello, nuestro héroe se configura como un magnífico poeta épico, capaz de relatar sus viajes haciendo gala de una conciencia estética tal, que demuestra sobradamente su pericia en las artes poética y retórica. Su relato semeja más al de Ulises que al de Eneas, aun cuando su palabra seduzca a Sinforosa tanto como la del héroe troyano a Dido, pues carece del hondo patetismo trágico con que reviste el fundador de Roma la destrucción de Troya, para derivar hacia los diversos tonos y múltiples escenarios del cuento de viajes y aventuras del de Ítaca. De modo que su

19. Carlos García Gual, Los orígenes de la novela, Madrid, Istmo, 1991, p. 125.

20. Cervantes, Don Quijote de la Mancha II, F. Sevilla Arroyo y A. Rey Hazas (eds.), Madrid, Alianza (Obra completa, vol. 5), 1996, cap. XVII, p. 807.

21. Hasta un total de seis. A saber: la de la isla de los pescadores (II, X-XI), el encuentro con el rey Leopoldio de Danea (II, XIII), con Sulpicia y su séquito de Amazonas (II, XIV), la del pez náufrago (II, XV), el sueño de la isla paradisíaca (II, XV) y la del mar glacial, el encuentro con Cratilo y la domesticación de su caballo (II, XVI, XVIII y XX). 
historia está repleta de incidentes varios, de lances extraordinarios, de lugares exóticos, de motivos casi fantásticos, que bordean constantemente la inverosimilitud. Aunque como relator de sus aventuras cuenta con la fiabilidad de su palabra, la única capaz de rememorarlas con la precisión de lo vivido, como poeta tiene la licencia de engalanarlas con metáforas, de estilizarlas, de exagerarlas y aun de inventarlas. Y así es como lo entienden los receptores de su larga narración cuyos comentarios atienden más al valor estético del relato que a otra cosa, es decir, lo enjuician crítica y metafictivamente, desde la adecuación o no de las interpolaciones hasta su verosimilitud, desde la aquiescencia hasta el desacuerdo ${ }^{22}$. El profesor García Gual ${ }^{23}$, comentando la narración de Ulises en la Odisea (cantos VIII-XII), subraya cómo los feacios, encabezados por Alcínoo, elogian sin paliativos la técnica oratoria del héroe y su sinceridad, o, lo que es lo mismo, que la valoración ajena del relato corresponde con la imagen heroica del narrador-personaje, de manera que no se osa poner en duda la veracidad de su palabra, aun cuando Ulises sea un consumado especialista en el arte del engaño y la mentira. Lo cual, continúa García Gual, no significa que el lector externo deba ser tan ingenuo como el rey de Feacia y sus príncipes y, por lo tanto, pueda plantearse «una inquietante cuestión: ¿cuándo cuenta la verdad y cuándo miente Odiseo? $\gg^{24}$. En el Persiles, por el contrario, los receptores del relato de Periandro sí que se hacen esa incómoda pregunta, que no solo incide en que el nuevo héroe ha de ganarse la confianza y el respeto de su público, sino que también denota que los valores épicos, y por ello la visión del mundo que conllevan, han cambiado ${ }^{25}$. Esto se debe, además, al modo en el que concibe Cervantes el criterio de la verosimilitud, el cual, más allá del uso de ciertas claves poéticas, redunda en la interacción emisor-receptor, narrador-narratario, pues, como afirmaba E. C. Riley, «en ningún aspecto como en éste [el de la verosimilitud] llega a basar Cervantes con más claridad su idea de la literatura como comunicación ${ }^{26}$. Por otro lado, el relato de Periandro, como el de Ulises y el de Eneas, cumple la función de completar parte del argumento de la novela. Desde esta perspectiva no es sino un recurso más de la novela bizantina clásica, pues es habitual que los personajes verbalicen sus aventuras para un auditorio, siendo la narración paradigmática la de Calasiris a Cnemón en la Historia etiópica de Heliodoro (libros II-V).

Estos dos planos narrativos que conforman el libro II mantienen un severo combate dialógico que sobrepasa los niveles puramente morfológicos. Es decir, más allá de la forma en que se expresan, la narración en tiempo presente y la relación de Periandro se relacionan entre sí tanto como se complementan y sirven de contraste la una de la otra. Nunca antes los dos componentes esen-

22. Véase J. GonzÁlez Rovira, La novela bizantina de la Edad de Oro, pp. 235-238; I. LozANO Renieblas, Cervantes y el mundo del «Persiles», pp. 72-76.

23. Introducción a su ed. de la Odisea de Homero, Madrid, Alianza, 2004, pp. 16-18.

24. Ibíd., p. 18.

25. Véase I. Lozano Renieblas, «Los relatos orales del Persiles», Cervantes, XXII, 2002, 1, pp. 111-126, especialmente pp. 122-123.

26. Teoría de la novela en Cervantes, p. 283. 
ciales de la novela sofística, el amor y las aventuras, se habían dividido en secuencias narrativas diferenciadas y simultaneadas concatenadamente, de tal forma que a una, la narración en tiempo presente, le correspondiese el tema del amor, en tanto que la otra, el relato homodiegético, se centrase en las aventuras. Lógicamente cada asunto precisa de un espacio específico en el que desarrollarse, y qué mejor que el ambiente cortesano, con sus obligados galanteos, para propiciar el escudriñamiento de la pasión erótica ${ }^{27}$ y el mar para que, con sus muchos peligros, surja la peripecia. Y de un tempo narrativo diferente: el estático y contemplativo para el amor, de forma que el interés redunde en la introspección psicológica; el dinámico y vertiginoso para la aventura, en el que se reflejen las virtudes heroico-cristianas del protagonista. Frente a la maraña de intrigas amorosas de la corte, que precisan, para su exposición, de la técnica del entrelazamiento ${ }^{28}$, se sitúa la sucesión, a modos de episodios en sarta, de las aventuras. Frente al realismo psicológico, las fantasías del viajero. Mas no sólo acontece una oposición contrastiva, sino que entre los dos planos narrativos se establece una relación de interdependencia estructural, pues el segundo de ellos deriva tanto como es propiciado por el primero, y temática, pues los temas de uno se reflejan o hallan una imagen especular en el otro, sobre todo lo que concierne a los asuntos sentimentales, que versan sobre las desviaciones irracionales del amor, la autognosis como guía para resolver los conflictos y el control racional del deseo ${ }^{29}$.

Pero es que la pericia técnica de Cervantes es tal que hace confluir los dos planos narrativos, justo al final del libro II, en un tercero: el episodio de Renato y Eusebia, en el que con genial maestría se añudan los tres en torno a un tema: el del amor contenido o la castidad como método de purificación del $\operatorname{deseo}^{30}$.

27. Dice a este respecto Octavio Paz: «El código de la cortesía está íntimamente ligado al código de la galantería; ambos son tentativas para regular, en el espacio cerrado del palacio, el juego de las pasiones» (Octavio Paz, Sor Juana Inés de la Cruz o las Trampas de la Fe, México, Fondo de Cultura Económica, 1985, p. 135).

28. Sobre esta técnica narrativa medieval característica de los libros de caballerías debe consultarse el excelente estudio de JuAn Manuel CACHo BlecuA, «El entrelazamiento en el Amadis y en las Sergas de Esplandián», Studia in honorem prof. M. de Riquer, Barcelona, Quaderns Crema, 1986, t. I, pp. 235-271. Véase, también, JuAn Bautista Avalle-Arce, «Amadís de Gaula»: El primitivo y el de Montalvo, México D. F., Fondo de Cultura Económica, 1990, pp. 147 y ss. Sobre su utilización en el palacio del rey Policarpo, véase ANA LUISA BAQUERO ESCUDERO, «La estructura narrativa en el episodio del rey Policarpo», Peregrinamente peregrinos, pp. 207-220; y de una manera más general, JUAN RAMÓN MuÑoz SÁNCHEZ, "Ortel Banedre, Luisa y Bartolomé: análisis estructural de un episodio del Persiles», pp. 147-148.

29. Huelga decir que la conformación de dos planos narrativos simultaneados concatenadamente vincula el libro II del Persiles con la segunda parte del Quijote, cuando el caballero y el escudero se separan para vivir cada uno su propia mentira, la de la corte, don Quijote; la del gobierno, Sancho. Curiosamente, esta duplicación narrativa, como la del Persiles, se genera cuando los protagonistas se detienen en un palacio, el de los duques.

30. Véase J. CASAlduero, Sentido y forma de «Los trabajos de Persiles y Sigismunda», pp. 129-137; Julio BaEnA, «Trabajo y aventura: el criterio del caballo», Cervantes, X, 1990, 1, pp. 51-57. 


\section{EL EPISODIO DE RENATO Y EUSEBIA: FORMA Y SENTIDO}

El episodio de Renato y Eusebia, que comprende los capítulos XVIII, XIX y XXI del libro II, presenta una morfología bastante sencilla, pero de una rentabilidad estética prodigiosa. En su mayor parte se trata de una relación intradiegética en la que un personaje, Renato, cuenta su desafortunado caso de amor y honra y su vida contemplativa al lado de Eusebia. Este bloque narrativo, sin embargo, se rodea de una mínima acción en el tiempo presente que sirve para marcar la atenuada irrupción del episodio y la presentación elocuente de los protagonistas así como para propiciar su desenlace. Esto es, el episodio se compone de una noticia, la que ofrecen los marineros a Periandro y compañía sobre la peregrina vida de los ermitaños franceses, que suscita el interés y la curiosidad por conocerlos, de un encuentro, el del grupo protagonista con Renato y Eusebia, de la narración de la historia y de la llegada de Sinibaldo, el hermano de Renato, que porta la buena nueva que concluye el episodio. Mas esta simplicidad compositiva se complica por la disposición del episodio sobre la trama de la novela, ya que se entrelaza con el fin de la narración de Periandro y con la acción principal, hasta el punto de que un personaje episódico de segundo orden, como es Sinibaldo, no solo anuncia el regreso a casa del ejemplar matrimonio francés, sino que, por sus noticias, acarrea que Artandro abandone momentáneamente sus intereses afectivos por Auristela a favor de sus obligaciones y deberes como príncipe heredero de Dinamarca y, de alguna manera, que el Persiles se sustraiga del ámbito del mito y el romance para adentrarse en los ásperos caminos de la historia y la novela contemporánea.

\section{LOS LIMINARES DEL EPISODIO: UN ENCUENTRO CARGADO DE RESONANCIAS}

Aún en plena fuga del laberinto de pasiones en que se han visto envueltos los héroes de la novela en la isla del rey Policarpo y rumbo a Inglaterra, que devuelve la narración al piélago, las aguas dormidas y unas nubes bajas anunciadoras de tormenta vienen a turbar el sosiego de los embarcados. Solo momentáneamente, pues la proximidad de una isla, «que se llamaba de las Ermitas» (II, 17, 246), promete cobijo seguro, mientras arrecie la borrasca, tanto para el barco como para sus moradores. De este modo, además, la comitiva de personajes podrá conocer de primera mano a los famosos ermitaños que la habitan, «cuya historia de los dos era la más peregrina que se hubiese visto» (II, 17, 246). Obligados por la necesidad y el deseo, unos cuantos del grupo, entre los que se cuentan los héroes principales, desembarcan a tierra firme con el fin de pasar allí la noche.

Las islas que jalonan la travesía septentrional del Persiles están repletas de historias que ayudan a amenizar, con el encanto del verbo, las incomodidades 
del viaje y los rigores del hospedaje. Así, en la Bárbara narró su periplo vital el español Antonio, en otra fría y montañosa hizo lo propio el italiano Rutilio, en una de nieve el portugués Manuel de Sosa relató su trágica experiencia amorosa, en Golandia se actualizó el vivir heroico de Transila, en la de Policarpo, por fin, Periandro iniciaba el relato de sus aventuras como corsario. Todas estas historias tienen como denominador común que responden, respecto al modo en que son interpoladas, al antiguo recurso técnico de sobremesa y alivio de caminantes.

La de las Ermitas, obviamente, no podía ser menos, y como a Periandro aún le restan peripecias por contar antes de dar por concluido su extenso relato, lo reanuda en el mismo punto en que lo dejó, para dar buena cuenta de su encuentro con el ejército de los esquiadores, el apresamiento suyo y del escuadrón que capitanea, su conducción por las mares helados y el cordial recibimiento que les brinda el rey Cratilo de Bituania, sobre todo después de que Sulpicia, su sobrina, reconozca en Periandro a «ese mancebo» en quien «tiene su asiento la suma cortesía y su albergue la misma liberalidad» (II, 18, 251). La feliz acogida, sin embargo, se ve relegada a un segundo plano por el rumor que levanta entre la muchedumbre presente un hermoso caballo del rey, que le trae por la calle de la amargura por su extremada braveza y su colérica furia, pues no consiente que nadie, ni siquiera él, lo monte. Mas con el auditorio subyugado por las excelencias narrativas de Periandro y cuando este se dispone a contar la increíble aventura del caballo, la isla reclama su atención para dar a conocer la historia que recoge en su interior.

Sabemos que Cervantes gusta sobremanera de cuidar al mínimo detalle la presentación de sus personajes, no solo porque con ello suscita la máxima expectación y sorpresa en los circunstantes y el lector, sino también porque la forma en la que acaece se reviste de significado, denota parte de la caracterización del personaje - o los personajes - y del estado en el que se encuentra. Una de las más célebres, por la plasticidad y ambigüedad que rezuma, es la de Dorotea vestida de hermoso galán que desnuda su pie y lo baña cuidadosamente en las aguas cristalinas de una fuente en mitad de Sierra Morena, para sabroso deleite del cura, el barbero y Cardenio, en el Quijote de 1605; o la del alférez Campuzano, amarillo y flaco y apoyándose en su espada como si fuera un bastón para caminar, a la salida del hospital de la Resurrección, en El casamiento engañoso, luego de curarse unas bubas. Puede, sin embargo, que la más audaz y arriesgada de todas, por su vaguedad semántica, sea la presentación, en el amanecer del Persiles, de Periandro y Auristela, ambos travestidos y en peligro de muerte, soportando como pueden la cadena de trabajos que el destino y la fortuna les ponen en su camino a la dicha. Pero la más portentosa es la de don Quijote por su relevancia en la historia de la literatura, al convertirse, por capricho de su voluntad, en caballero andante, de modo que a contrapelo de los héroes de la épica clásica, de la caballeresca y aun de los de la picaresca, para ser lo que quiere ser, no tenga sino que abjurar de lo que es, y así poder hacer, de su vida, literatura, o sea convertirse en su sueño. Pues bien, la de Renato y Eusebia es tan elocuente como la de todos estos personajes: 
A la escasa luz de la luna, que cubierta de nubes no dejaba verse, vieron que hacia ellos venían dos bultos que no pudieran diferenciar lo que eran (II, 18, 252).

Pues, efectivamente, aquellos que han decidido arrebujarse con la manta de la vida silenciosa y solitaria, lejos del mundo civilizado y en paz consigo mismo no pueden ser sino eso: dos sombras en la oscuridad nocturna. Es decir, nadie. Puesto que se han despojado de todo cuanto hace al hombre un ser social, se han desnudado de todo oropel para adentrarse en la rutina esencial de las cosas mínimas y el olvido.

Lo primero que advierte el grupo, luego del misterio provocado por la llegada a deshora de los moradores de la isla, es la voz de la benevolencia que quiere no más que servirlos y acogerlos con la sencillez de sus medios. De manera que Renato y Eusebia, hechas las presentaciones, se erigen en los guías del grupo y conducen a Periandro y compañía hasta una cima en la que se levantan dos ermitas, «más cómodas para pasar la vida en su pobreza que para alegrar la vista con su rico adorno» (II, 18, 253). Cervantes, como consumado perito en el uso de la voz narrativa, en determinados pasajes de sus obras en prosa combina con maestría y precisión la posición de omnisciencia olímpica del narrador con la de equisciencia, que iguala el conocimiento del narrador con el del personaje, humaniza su saber, y así aproxima la posición del lector a la del personaje, al que suspende y admira ${ }^{31}$. Para realizar esta operación, en algunas ocasiones el narrador utiliza a los personajes en la función de reflectores, en cuanto que se sirve de sus ojos para describir el ambiente. $\mathrm{O}$ sea, el narrador ve lo que ven sus personajes ${ }^{32}$. Este cambio de punto de enfoque es el que acontece en el episodio de Renato y Eusebia, pues lo que describe el narrador no es sino aquello que escudriñan los ojos del grupo:

31. Es importante subrayar, por otro lado, que la écfrasis era ya un componente retórico importante en la épica antigua — piénsese, por ejemplo, en la descripción que de los principales héroes argivos efectúa Helena a petición de Príamo, en la Ilíada (canto III), donde Homero sigue la estrategia de servirse del personaje en función de reflector, y, sobre todo, en la descripción del escudo de Aquiles (canto XVIII) - , que, sin embargo, alcanzará su cenit en las letras antiguas con los poetas alejandrinos y sus seguidores romanos, los neotéricos o los poetae novi, cuyo ejemplo más ilustre en la écfrasis de la historia de Ariadna del poema 64 de Catulo; con Virgilio, otro especialista en la utilización del punto de vista narrativo, principalmente en la Eneida, y con los novelistas, especialmente los de la Segunda Sofística, pues no de otro modo Longo y Aquiles Tacio siguen el precepto horaciano del ut pictura poesis al inaugurar sus textos con sendas écfrasis de cuadros, en los que se consigna el argumento o parte de él. Cervantes, aparte del uso que hace de la descriptio en el episodio, se servirá ampliamente de ella en el Persiles, de forma notoria por medio del cuadro que manda pintar Periandro en Lisboa de sus aventuras atlánticas (véase CARLOS BRITO GARCÍA, "“Porque lo pide así la pintura”: la escritura peregrina en el lienzo del Persiles», Cervantes, XVII, 1997, 1, pp. 145-164; A. REy y F. SEvilla, Introducción al Persiles, pp. XXXVIII-XLI).

32. El caso más sobresaliente en la combinación de perspectivas es el de Rinconete y Cortadillo, novela en la que se pasa de un narrador omnisciente neutro, que muestra el encuentro y las correrías de los dos pícaros, a otro equisciente, que describe el patio de Monipodio a través del filtro visual de los dos mozuelos, que pasan de actuar a ser espectadores de excepción. Pero donde mayor rendimiento literario se obtiene y la complicación llega a límites insospechados es en el Quijote (véase E. C. RILEY, Introducción al «Quijote», trad. de E. Torner Montoya, Barcelona, Crítica, 2000, pp. 183-194). 


\begin{abstract}
... vieron dos ermitas [...]. Entraron dentro, y, en la que parecía algo mayor, hallaron luces que de dos lámparas procedían, con que podían distinguir los ojos lo que dentro estaba, que era [...]; notaron los pobres vestidos [de los dos ermitaños], la edad, que tocaba en los márgenes de la vejez; la hermosura de Eusebia, donde todavía resplandecían las muestras de haber sido rara en todo estremo [...]. Corrió el tiempo como suele, voló la noche, y amaneció el día claro y sereno [...] y salieron a ver desde aquella cumbre la amenidad de la pequeña isla... (II, 18, 253-254).
\end{abstract}

Dos parecen ser las funciones principales que derivan del cambio de perspectiva: por un lado, la descripción del lugar como una suerte de paraíso terrenal $^{33}$, de Renato y Eusebia como dos figuras engrandecidas por su carestía y su trato afable, y de su vida simple y virtuosa dedicada al contacto con la naturaleza y a la contemplación divina. Por otro, y en perfecta sintonía con la anterior, propiciar, desde la óptica de unos personajes que recién llegaron de la bulliciosa, voluptuosa y engañosa vida de palacio, un menosprecio de corte y alabanza de aldea $^{34}$. La situación creada no dista mucho de la que acontece en La Galatea, cuando unos cortesanos, Timbrio, Nísida, Blanca y Darinto, arriban a las riberas del Tajo y, tras notar la quieta y saludable vida de los pastores, entonan, desde su perspectiva mundana, un himno de aldea. Ocurre, sin embargo, que en el Persiles Cervantes va un paso más allá en la complicación narrativa del tópico bucólico, pues, además del contraste creado entre la vida cortesana de la isla de Policarpo y la retirada de la isla de las Ermitas, se genera otro entre el brillo fastuoso y asombroso de la narración de Periandro con la sencillez pura del modo de vida agreste de los ermitaños. Aquí la fatuidad del viajero, su exotismo y sus peripecias se reducen a la vida cotidiana, anodina y regalada de la isla. Más aún, pues la equiparación contrastiva entre los dos modos de vida se registra asimismo en la propia historia de los castos amantes, y es uno de sus temas principales.

\title{
LA NARRACIÓN DE RENATO: LITERATURA Y VIDA
}

En efecto, después de una humilde y frugal comida Renato, a petición de Arnaldo, cuenta su historia. Al comenzar el relato de sus peripecias en los mares helados, Periandro aseguraba a su auditorio que es «dulcísima cosa contar en tranquilidad la tormenta» (II, 18, 248), Renato, en cambio, advierte de que «eso no podré decir de los míos, pues no los cuento fuera de la borrasca, sino

33. Véase J. CASAlduero, Sentido y forma de «Los trabajos de Persiles y Sigismunda», p. 131; y A. K. Forcione, Cervantes' Christian Romance, pp. 72-77.

34. Así, por ejemplo, AURORA EGIDO afirma que «la pureza de la vida ermitaña se confirma aquí como emulación de la vida palaciega, llena de vicios y engaños [...], un canto de aldea que remite a la negación de lo cortesano» («El eretismo ejemplar. De La Galatea, al Persiles», Cervantes y las puertas del sueño, Barcelona, PPU, 1994, pp. 333-348, la cita corresponde a la p. 340). 
en mitad de la tormenta» (II, 19, 255). De modo que la historia del francés, a diferencia de la extensa del héroe principal, está aún en curso, a la espera de resolverse en el tiempo presente de la novela, o, lo que es lo mismo, empieza por el medio de los hechos, por lo que su circunstancia actual como ermitaño no es definitiva, sino un modo de vida transitorio, una especie de paréntesis vital lejos del medio social al que pertenece.

La estructura del Persiles, como se sabe, descansa sobre el viaje que los amantes nórdicos efectúan, obligados por las circunstancias, desde Tule hasta Roma. Un largo periplo por un mundo caótico repleto de accidentes, violencias variadas y trabajos que se divide en dos: por un lado, el que se desarrolla de sur a norte por los fríos mares septentrionales de Europa; por otro, el que transcurre de oeste a este por los polvorientos caminos meridionales que conducen de Lisboa a Roma. A cada zona le corresponde un tipo de viaje específico: por mar y por tierra, respectivamente; un tipo de aventura; un criterio dispar de verosimilitud, y aun de tendencia narrativa, que aproxima el viaje por mar a la prosa de ficción idealista y al mito o la leyenda, mientras que el terrestre se ajusta más a la novela contemporánea y el costumbrismo. Esto es, Cervantes opera con un doble concepto de cronotopo: el de la novela griega y el del camino ${ }^{35}$. Pero esta separación de mundos no es total, sino que se interfieren y se interrelacionan continuamente, merced a una urdimbre narrativa hilvanada de simetrías, paralelismos y de tráfico de personajes de un orbe al otro ${ }^{36}$. Pues bien, la de Renato es una de las vidas que comporta la entrada del sur en el norte europeo, junto con las del español Antonio, el italiano Rutilio y el portugués Manuel de Sosa. Todas ellas, aparte de marcar los territorios nacionales por los que transcurre el itinerario meridional de la novela, tienen en común que sus protagonistas, arrastrados por sus errores y sus fracasos, arriban al Septentrión, en cuyas islas hallan la ocasión de expiar sus culpas tras un doloroso proceso de autognosis, para después, como sujetos renovados, emprender el camino de regreso a casa, con la sola excepción del enamorado portugués, que termina, muerto de amor, sepultado en sus frías nieves. Es decir, describen un camino de ida y vuelta, una odisea en la que el retorno, a pesar de las dificultades y de los obstáculos hallados, supone el logro de un conocimiento que reafirma una personalidad. Un esquema compositivo vital que hunde sus raíces en la Odisea de Homero y que repite, asimismo, el de la novela de tipo griego y aun el del Persiles. Lógicamente, entre unas historias y otras se registran variaciones significativas que las individualizan del conjunto, pero no por ello dejan de mostrar un esquema

35. Véase Mijail Bajtin, Teoría y estética de la novela, Madrid, Taurus, 1989, pp. 237-409. Las teorías del formalista ruso han sido aplicadas al Persiles y a la novela bizantina española por I. LOZANO Renieblas, en Cervantes y el mundo del «Persiles», y Emilia I. DefFis De Calvo, Viajeros peregrinos y enamorados, Pamplona, Eunsa, 1999. Desde otro enfoque más tradicional, véase E. C. RILEY, «Tradición e innovación en la novelística cervantina», Cervantes, XVII, 1997, 1, pp. 46-61.

36. Véase C. Romero, «Introducción» a su edición del Persiles, Madrid, Cátedra, 1997, pp. 37-42; A. ReY y F. SEVILlA, «Introducción» a su edición del texto, ya citada, pp. XX-XLV. 
morfológico parecido y una vinculante unidad de sentido sintáctico y semántico.

La narración intradiegética de Renato tiene como objetivo la exposición de los motivos que le han conducido a él y a Eusebia a estar donde están y a vivir como viven. De su pasado, pues, selecciona solamente aquellos incidentes que son estrictamente necesarios para comprender la situación a la que ha llegado, aquellas vivencias que constituyen los hitos fundamentales de su andadura vital. Ello implica, entre otras cosas, que Renato es, simultáneamente, protagonista y narrador de su cuento, lo cual le confiere una incuestionable dualidad como personaje. Mas sin embargo, es significativo subrayar que, frente a lo que le sucede a Periandro con la recepción de su relato, su palabra no será jamás puesta en entredicho por sus interlocutores.

El francés Renato es un perfecto caballero cortesano. Hijo de padres nobles y ricos, recibió una educación esmerada y acorde con su estado. Comedido en el trato y discreto en lo que respecta a los asuntos del corazón, se enamora de una camarera de la reina, Eusebia, a quien no osa declarar su amor más que con los ojos, acaso porque los enamoramientos se producen en principio por mediación de la vista, cuya función no es otra que la de incrustar los sentimientos en las almas, según reza el platonismo dominante de la época. Ella, como cabe esperar de una dama honesta y virtuosa, no cae presa en la red amorosa de sus miradas ni le hace caso alguno, de modo que «ni con sus ojos ni con su lengua me dio a entender que me entendía» (II, 19, 255). Pero el secretismo de su encendimiento no es tal, que la demasiada curiosidad y la mucha malicia que se respira en el ambiente de la corte no se hagan eco de él. Y así, otro caballero, Libsomiro, sabedor de los sentimientos de Renato, y envidioso de ellos, le va con el cuento al rey de Francia de que entre Eusebia y nuestro narrador ha surgido un amor ilícito que lo deshonra y ofende ${ }^{37}$. El rey, alborotado, le manda llamar para que se explique y Renato no hace sino advertir la mentira y salir en favor de la honra de la camarera de la reina. Por lo que el conflicto habrá de resolverse mediante la celebración de un juicio de Dios.

La falsa acusación es un motivo más que corriente en la narrativa, literaria o folclórica, de todos los tiempos, que se incorpora rápidamente al repertorio de la novela helenística de amor y aventuras como uno de los trabajos a los que debe enfrentarse la pareja protagonista para acrisolar su amor. Consecuencia de la calumnia es que los amantes sufran vejaciones, condenas, maleficios, castigos, prisiones, celos, deshonras. Buena prueba de ello es la acusación de adulterio que Tersandro hace recaer sobre Clitofonte (libros VI) y de impureza sobre Leucipa (libro VII), en la novela de Aquiles Tacio; así como la de Ársa-

37. Libsomiro, por tanto, oficia el papel de los lausengiers o maldicientes, que eran, en la tradición del amor cortés, de la que es ampliamente deudor el episodio del Persiles, aquellos espías del amor de los amantes que intentaban conocer su intimidad y estaban dispuestos a calumniarles, por envidia, por celos o por cualquier otro pretexto desestabilizador, con el objetivo de frustrar su relación. Andret, Ganelón, Godoine y Denoalen, los barones felones de la leyenda medieval de Tristán e Iseo, son probablemente los ejemplos más preclaros. 
ce, en la Historia etiópica de Heliodoro, de que Cariclea ha envenenado a una de sus criadas, la hechicera y celestina Cíbele (libro VIII) y, antes, la de Deméneta, que acusa falazmente a su hijastro Cnemón de pretender relaciones eróticas con ella ante su padre (libro I), que responde al tema de la hija de Putifar, cuyo paradigma, en la Antigüedad, era la historia de Fedra, en el Hipólito de Eurípides. Pero es en el ambiente cortesano caballeresco medieval, del que surgen los libros de caballerías y la novela sentimental, en el que se reproduce hasta la lujuria, bajo un esquema reiterativo, aunque varíe en este o en aquel aspecto, que consiste en que una dama principal es víctima de una calumnia sobre su reputación que, con harta frecuencia, provoca su encarcelamiento, dado que no puede probar su inocencia. El conflicto de honra se ve abocado para su resolución a un duelo de armas entre el acusador y el caballero que salga en su defensa. La victoria decidirá su culpabilidad o su inocencia. Casos arquetípicos de denuncia mentirosa son: la que Mador de la Puerta emite contra la reina Ginebra en La muerte del rey Arturo (c. 1230) y la historia de Ginebra y Ariodante (cantos IV y V) del Orlando furioso (1532, edición definitiva) de Ariosto. Diferente es la estratagema que urde la Viuda Reposada, en Tirante el Blanco (1511, la traducción castellana) de Joanot Martorell, para hacer creer a Tirante que su amada Carmesina mantiene relaciones deshonestas con un hortelano (capítulos 284-287) 38 . Cervantes utiliza este tópico literario en varias ocasiones y siempre desde una perspectiva y un alcance diversificados, pues como es corriente en su obra la vida triunfa sobre la teoría. Conviene saber, en La gitanilla, donde la Carducha acusa de ladrón a Andrés, suscitando la prisión del gitano fingido y propiciando el rápido desenlace de la historia; en $E l$ laberinto de amor, cuya enrevesada trama se erige sobre la falsa denuncia: Dagoberto, enamorado de Rosamira, y confabulado con ella, para impedir que se celebre el casamiento concertado de esta con Manfredo, la acusa de deshonesta y remite la solución del caso a un juicio de Dios; en la Segunda parte del Quijote, Altisidora levanta testimonio al caballero andante por culpa de unos tocadores y unas ligas; en el Persiles, por fin, la cortesana Hipólita denuncia a Periandro de ladrón, consiguiendo su inmediata detención. Habida cuenta de que los rasgos de la acusación falaz están muy generalizados, resulta casi imposible discernir las fuentes precisas con las que trabaja Cervantes. Pero no así su clasificación, en tanto que las acusaciones de ladrón que profieren, como consecuencia de la humillación vengativa de la mujer rechazada, la Carducha, Altisidora e Hipólita semejan entre sí tanto como el falso testimonio que levantan Dagoberto y Libsomiro sobre la honra de Rosamira y Eusebia, respectivamente. Pues, en efecto, El laberinto de amor y el episodio de Renato plantean un conflicto de honra entendida como reputación, que únicamente puede resolverse mediante un duelo de armas. Mientras que las falsas denuncias de la Carducha e Hipólita podrían devenir de la novela griega, dado que son varia-

38. Véase Jean Canavaggio, Cervantès dramaturge. Un théâtre à naître, Paris, Preses Universitaires de France, 1977, pp. 110-115. 
ciones del tema bíblico de la mujer de Putifar, las de Dagoberto y Libsomiro se adscriben a la tradición caballeresca. El caso de Altisidora es diferente, ya que se trata de una parodia de la acusación mentirosa, que si apunta más al orbe caballeresco es por la condición de caballero aventurero de don Quijote.

El juicio de Dios tendrá que celebrarse en «una de las ciudades libres de Alemania» (II, 19, 256) y no en París, como consecuencia de la negativa del rey de darles campo seguro, puesto que los duelos públicos fueron prohibidos por decreto por la iglesia católica durante la sesión XXV del Concilio de Trento. Allí tiene lugar el desafío según rezan las formas de la caballeresca, vigiladas por los padrinos y jueces de campo, que aseguran la igualdad en armas, no más que escudo y espada, y la partición del sol en el campo de batalla. Renato se presenta tan confiado por tener la verdad de su lado como arrogante y soberbio Libsomiro. Como bien dice James R. Stamm, «Cervantes trabaja siempre dentro de los moldes tradicionales y establecidos, si bien en sentido sumamente original» ${ }^{39}$. Ello es que nuestro autor da una solución inesperada al conflicto al no triunfar la verdad y el bien sino la mentira y el mal, a contrapelo de lo que sucedía ordinariamente en los libros de caballerías, así como en la ordalías de la novela de tipo griego. Renato, a pesar de haber puesto la esperanza en Dios y en su buen hacer, es derrotado por Libsomiro, de modo que la deshonra de Eusebia queda confirmada. Este giro insólito bien podría interpretarse como una denuncia a este ritual, en el que un aspecto tan grave como la puesta en entredicho de la honorabilidad de una dama hubiera de resolverse al arbitrio de las armas y no con la búsqueda y el perseguimiento de la verdad, ya que la confirmación de la culpa comportaba la muerte física de la mujer, o cuanto menos su defunción pública, que la invalidaba para cualquier acto social en vida. Cierto es que también está en consonancia con los aires nuevos que respira la literatura de ficción en su aproximación a la incertidumbre de la vida, donde no siempre triunfa la justicia y donde la artificiosidad huera del arquetipo se mide por el rasero de la realidad; así como con el advenimiento de la pérdida de la confianza y la fe en los valores universales, trivializados, relativizados y subjetivizados por el acomodo de una nueva ideología, la de la filosofía de los puntos de vista, que interpreta el mundo de otro modo, y que inaugura la modernidad.

Sea como sea, sucede que Renato, derrotado y «en poder del quebranto y de la confusión» (II, 19, 257), vacila en un mar de cuitas, sufre un profundo ataque de melancolía y vergüenza, hasta el punto de hacérsele imposible la vida en la corte, ya que adivina su deshonra en todo aquello que observa y escucha. Y, así, arrastrado por estos delirantes extravíos de la razón, opta por abandonar su patria y encaminarse a un lugar donde no se tenga la mala noticia de su infamia. Su caso, como dijimos, no dista mucho de los de Antonio, Rutilio y Manuel, pero la decisión del francés es más extrema, pues deriva del hon-

39. «La Galatea y el concepto del género: un acercamiento», Cervantes. Su obra y su mundo, Manuel Criado del Val (ed.), Madrid, Edi-6, 1981, pp. 337-343, en concreto p. 343. 
do y agitado proceso psicológico en que le sume su deshonra. Se trata, en fin, de una elección premeditada y no de un capricho de la fortuna, como lo corroboran los preparativos del viaje. Renato, antes de marchar, cede toda su hacienda a su hermano y, después, acompañado de sus criados, parte en busca de un lugar que se acomode a la nueva vida que ha decidido llevar, hasta que se topa con esta isla despoblada desde la que rememora su bella historia. En ella, luego de levantar una ermita, despide a su servicio, pero con la condición de que vengan cada año para traerle sustento y, en caso de haber fallecido, para que entierren sus huesos. Solo y sepultado en el silencio de su rincón, Renato halla la dicha que disculpa su fracaso y se felicita por haber abandonado la vertiginosa vida en sociedad de la corte. Es decir, entona una epifanía en alabanza de la vida retirada del tráfago del mundanal ruido:

\footnotetext{
¡Oh soledad alegre, compañía de tristes! ¡Oh silencio, voz agradable a los oídos, donde llegas, sin que la adulación ni la lisonja te acompañen! ¡Oh qué cosas dijera, señores, en alabanza de la santa soledad y del sabroso silencio! (II, 19, 257).
}

No cabe dudar, desde luego, de la sinceridad de las palabras de Renato, pero el elogio del aislamiento en contraposición al bullicioso mundo de la ciudad no es una elección de vida en y por sí misma, sino que es la consecuencia de un conflicto ignominioso: su incapacidad para haber demostrado con las armas la limpieza de Eusebia y el falso testimonio de Libsomiro. De modo que cuando se resuelva la situación por el arrepentimiento de este y recupere tanto la honorabilidad como la hacienda perdidas, no dudará lo más mínimo en regresar al mundo del engaño, la apariencia y el galanteo. Será, lógicamente, la recompensa merecida por haber resuelto felizmente su caso ante Dios y ante los hombres. Mas también se trata de otra rectificación, la del tópico enfrentamiento aldea-corte, ahora desde la perspectiva del sentir de una nueva época, la del Barroco, que se singulariza, en función de sus características morales, políticas, económicas, sociales y culturales, por ser predominantemente urba$\mathrm{no}^{40}$. En efecto, después de que los escritores clásicos celebraran las ventajas de la vida retirada sobre las de la ciudad, cifradas en el Beatus ille de Horacio, el tópico literario filosófico tuvo un resurgir apoteósico durante el Renacimiento, en el sentido en que se adecuó perfectamente a su pensamiento, a su sensibilidad y a sus distintas modalidades genéricas, como lo atestiguan el famoso Menosprecio de Corte y alabanza de Aldea (1539) de fray Antonio de Guevara o la no menos conocida oda I de fray Luis de León, La vida retirada, pero sobre todo la novela pastoril, en cuanto que conlleva implícitamente el elogio de la aldea. Sin embargo, a medida que se aproxima el ocaso del siglo XVI, el lugar común tiende a atenuar la distancia entre campo y ciudad, hasta la equidad, o a relativizarla desde el vivir circunstancial, como lo ejemplifica nuestro caso. Lo echamos de ver, además, en La Galatea, donde el cor- 
tesano Darinto, después de haber alabado la excelencias del modo de vida pastoril, se mantiene apegado a su condición urbana cuando padece el revés amoroso de Blanca ${ }^{41}$, y en la comedia de Lope de Vega, El villano en su rincón (1617), en la que el campesino Juan Labrador, aislado en sus dominios rurales, se verá obligado por el rey a visitar y a vivir en la corte, de modo que se cohonestan los dos pareceres. En el Persiles se reviste de otro significado más, que apunta a su lección última, en la medida en que es la aceptación de la vida social la que se preconiza y defiende sobre cualquier tipo de apartamiento.

Antes del regreso, sin embargo, la existencia solitaria de Renato se verá felizmente truncada por la llegada inesperada de Eusebia al transcurrir el primer año de estancia en la isla de las Ermitas. Ello es que el episodio no solo pivota sobre un caso de honra, sino también sobre la fuerza del amor que arrastra a los corazones en busca de la persona amada ${ }^{42}$. Eusebia, por lo tanto, pertenece a ese elenco de personajes femeninos de Cervantes que abandonan casa y hacienda y ponen en entredicho su honra por salir al encuentro de su amante, o sea, se convierte en una peregrina de amor: a fin de cuentas, «hacer uno solo de dos y sanar la naturaleza humana $»^{43}$ es la base amorosa de la obra. Pero Eusebia ni ha sido burlada ni ha sufrido un encierro que oprima su libertad, ni siquiera ansía la unión con Renato, sino que viene a ser su compañera de fatigas por una culpa que no han cometido:

Eusebia [...], agradecida a mis deseos y condolida de mi infamia, quiso, ya que no en la culpa, serme compañera en la pena (II, 19, 258).

De este modo, en el destierro, libres del protocolo social, Renato y Eusebia pueden vivir, en su vergel, su particular historia de amor, pues celebrarán sus desposorios al modo pretridentino, sin más ritos ni ceremonias que darse las manos ante los ojos de Dios ${ }^{44}$. Sin embargo, no saborearán las mieles del matrimonio, sino que, frenando sus impulsos, se mantendrán puros. Son, como felizmente los designara Luis Rosales, «los vírgenes esposos del Persiles» ${ }^{45}$. Y aun de la obra de Cervantes, pues no hay correspondencia alguna con ningún otro caso de amor, dada la extremosidad de su castidad y del dominio absoluto de sus pasiones, «ambos — como sostiene Aurora Egido ${ }^{46}$ — componen la nueva pareja edénica en una isla paradisíaca donde lavan culpas ajenas, su-

41. Véase Juan Bautista Avalle-Arce, La novela pastoril española, Madrid, Istmo, 1974, pp. 244-245; JuAN RAMÓN MuÑoz SÁNCHEZ, «Un ejemplo de interpolación cervantina: el episodio de Timbrio y Silerio en La Galatea», Anuario de Estudios Filológicos, XXVI, 2003, pp. 279-297.

42. Véase A. EGIDo, «El eretismo ejemplar. De La Galatea, al Persiles», p. 341.

43. Sobre este aspecto de la filosofía platónica del amor, derivado del mito del hombre esférico del Banquete (189c-193e), y su evolución histórica, véase el excelente estudio de GuILLERMO SERÉS, La transformación de los amantes, Barcelona, Crítica, 1996.

44. Sobre el tema del matrimonio en el Persiles, véase M. Nerlich, El «Persiles» descodificado, pp. 571-576; J. R. MuÑoz SÁNCHEZ, «Ortel Banedre, Luisa y Bartolomé...», pp. 130-132.

45. Luis Rosales, Cervantes y la libertad, 2 vols., Madrid, Gráficas Valera, 1960, vol. I, p. 224.

46. «El eretismo ejemplar. De La Galatea, al Persiles», p. 342. 
perando los estragos de una deshonra ficticia». Su historia de amor contenido, por tanto, se erige en baluarte de una perfección moral y espiritual de sentido neoplatónico, en función de las numerosas afinidades que guarda con ella: el culto a la belleza física, en tanto que el amor nace de la vista de un cuerpo hermoso, las escalas del amor, que va en grados de lo físico a lo espiritual, el elogio a la castidad, como práctica de purificación, y la visión del amor como vía para llegar a Dios. Pero leamos las hermosas palabras de Renato:

\begin{abstract}
Recebíla como ella esperaba que yo la recibiese, y la soledad y la hermosura, que habían de encender nuestros comenzados des[e]os, hicieron el efeto contrario, merced al cielo y a la honestidad suya. Dímonos las manos de legítimos esposos, enterramos el fuego en la nieve, y en paz y en amor, como dos estatuas movibles, ha que vivimos en este lugar casi diez años [...], dormimos aparte, comemos juntos, menospreciamos la tierra, $y$, confiados en la misericordia de Dios, esperamos la vida eterna (II, 19, 258).
\end{abstract}

Se trata, en fin, de una historia de amor resignado y virtuoso que sirve de refuerzo de la de Periandro y Auristela, pero al mismo tiempo de contraste, pues la pureza virginal y la confianza ciega en la divina Providencia de los nobles franceses se desarrolla en la soledad de la isla, mientras que la de los amantes nórdicos se acrisola en el roce continuo con las distintas formas de sociedad que hallan en su laberíntica peregrinación por el mundo. Y así es como lo entiende Periandro, en cuanto que, nada más finalizar su cuento Renato, interrumpe el debate que había suscitado la vida retirada de los ermitaños franceses, para narrar la increíble aventura del caballo de Cratilo ${ }^{47}$, en la que ejemplifica alegórica y simbólicamente cómo se pueden domar la pasiones y el instinto en el tráfago de la vida activa. Es decir, opone el modo de vida contemplativo y fácil de Renato al suyo propio.

El caballo desenfrenado como símbolo de los sentidos no domeñados por la razón, sobre todo en la juventud, es, desde el excepcional mito de la biga alada del Fedro (246a-256e, sobre todo 254c y ss.) de Platón, un motivo filosófico literario común y, por ello, más que frecuente. Sírvanos como botón de muestra estas significativas palabras de Alonso de Barros en el Elogio que dedica a la primera parte del Guzmán de Alfarache (1599) de Mateo Alemán:

Dándonos a entender [Mateo Alemán] con demostraciones más infalibles el conocido peligro en que están los hijos que en la primera edad se crían sin la obediencia y la dotrina de sus padres, pues entran en la carrera de la juventud en el desenfrenado caballo de su irracional y no domado apetito, que le lleva y despeña por uno y mil inconvenientes ${ }^{48}$.

Sin olvidar que, ya en tierras meridionales, el impulsivo polaco Ortel Banedre hará su entrada en el Persiles cayéndose, harto significativamente, de su caballo.

47. Véase A. K. Forcione, Cervantes, Aristotle and the «Persiles», pp. 245-254. p. 116.

48. Mateo Alemán, Guzmán de Alfarache, José María Micó (ed.), Madrid, Cátedra, 1994, t. I, 
El caso es que Cratilo se encuentra desasosegado porque es incapaz de domesticar su hermoso y fiero caballo; y Periandro, que no quiere sino agradar al rey de Bituania y demostrar con los hechos las amables palabras de Sulpicia, decide acometer la hazaña. De modo que se monta a lomos del indómito caballo, lo conduce hasta el borde de un precipicio y lo hace saltar por los aires al mar helado, dándose un duro golpe, que no acaba con la vida de nuestro héroe narrador gracias a la poderosa fuerza del equino, que se mantiene en pie tras la caída. Periandro, sin embargo, más temerario que valiente, vuelve a montarlo y a conducirlo otra vez hasta el despeñadero, pero sin conseguir que el caballo vuele de nuevo, pues esta vez refrena su ímpetu y se clava en el borde del acantilado. Lo más relevante, empero, es que el salvaje equino «cubrióse luego de un sudor de pies a cabeza, tan lleno de miedo, que le volvió de león en cordero y de animal indomable en generoso caballo, de manera que los muchachos se atrevieron a manosearle» (II, 20, 261). El heroísmo de Periandro es, por lo tanto, el mismo que el de Renato, pues los dos han aprendido a dominar sus sentimientos y a conducirse por la fría razón, si bien por caminos opuestos, este en la soledad, aquel en la sociedad, o, dicho de otro modo, la analepsis completiva del actor masculino principal de la novela y el episodio de los ermitaños franceses convergen, en este punto, en el tema sobre el que versan, alternando en la disposición en la fábula y además desde perspectivas narrativas bien distintas.

\section{LA LLEGADA DE SiNIBALDO: EL REGRESO A LA SOCIEDAD Y EL ENCUENTRO CON LA HISTORIA}

Luego de la narración de la aventura del caballo de Cratilo, Periandro pone fin al cuento de sus aventuras como corsario enlazando su historia con el principio de la novela. Si bien aún resta por saber su origen y el de Auristela, así como el conflicto que les puso en camino, amén de los trabajos sufridos por la heroína en solitario, que no osa tomar el relevo a su hermano amante por no cansar al paciente auditorio, «ni, aunque quisiera, tuviera lugar para hacerlo, porque se lo estorbara una nave que vieron venir por alta mar encaminada a la isla, con todas las velas tendidas») (II, 21, 264).

Se trata, naturalmente, de la visita anual que reciben Renato y Eusebia. Esta, a diferencia de las anteriores, trae consigo la sorpresa de Sinibaldo, el hermano del ermitaño francés, que viene con las alforjas repletas de noticias.

En efecto, hechos los saludos pertinentes y sin dilación, Sinibaldo se dirige a los castos esposos para informales de la muerte de Libsomiro y de su arrepentimiento de última hora, en el que «confesó la culpa en que había caído de haberos acusado falsamente» (II, 21, 265). Sin embargo, su contrición no se detuvo ahí, sino que no paró mientes hasta que su caso no quedara como ins- 
trumento público para el futuro ${ }^{49}$. Lo más importante, de todos modos, es que predispone al rey de Francia a que, al saber la buena nueva, rehabilite la desahuciada honra de los ermitaños y mande buscarlos para recompensarlos con magnanimidad.

Para que no haya lugar al equívoco, el primero en dar el parabién a la ejemplar pareja, el príncipe Arnaldo, hace hincapié en el tema central del episodio, que no es sino el de la honra entendida como reputación:

La honra perdida y vuelta a cobrar con estremo, no tiene bien alguno la tierra que se iguale (II, 21, 265).

Eso sí, desde la mirada crítica de Cervantes, que nos habla del absurdo de la honra pública, capaz de marginar en vida a las personas, cuando lo esencial, como evidencian a las mil maravillas Renato y Eusebia, es ser firme en la privada.

Los dos primeros libros del Persiles se desarrollan, como hemos dicho, en el espacio desconocido y semilegendario del Septentrión europeo, en el que la concretización histórica se difumina en la leyenda y el mito, aunque los mares y las islas en los que se desarrolla la acción se adecuen perfectamente a los conocimientos que de ellos se tenía en la época. La Historia no más que tiene cabida en los diversos episodios intercalados que protagonizan personajes meridionales, como las campañas militares de Carlos V en Alemania, en las que participa el español Antonio, o las del rey de Portugal en el norte de África, que cuenta el portugués Manuel de Sosa. Datos históricos que, sin embargo, no tienen ninguna repercusión en el devenir de la historia principal, en tanto que no afectan ni intervienen en su desarrollo. La Historia también se inmiscuye en el episodio de Renato, tal la mención de que el rey de Francia no les diera campo de batalla a él y a Libsomiro en suelo francés. Pero mucho más significativas son las noticias que sobre la política europea cuenta Sinibaldo. Informa de la muerte del emperador, de las guerras de Transilvania, del imperio Turco y de la ardua situación en la que se encuentra el reino de Dinamarca por culpa de la ausencia del príncipe heredero, cuya causa, se rumorea, no es otra que la pasión desenfrenada que siente por una esclava suya. La Historia, esta vez, sí que repercute en la trama, puesto que suscita que Arnaldo postergue sus intereses sentimentales para con Auristela a fin de desempeñar sus obligaciones como heredero de Dinamarca, o, lo que es lo mismo, que los protagonistas principales puedan continuar su viaje a Roma desembarazados de pretendientes amorosos. Pero estos datos históricos también determinan de alguna manera lo que sigue, en la medida en que se sitúan en el margen fronteri-

49. Conviene señalar que el arrepentimiento de última hora es una constante en la obra de Cervantes, como así lo atestiguan el de Anselmo en El curioso impertinente, el del viejo Carrizales en El celoso extremeño, el del mayordomo de la madre de Constanza en La ilustre fregona, el de Alonso Quijano en el Quijote. El de Libsomiro, en la medida en que propicia y dispara el desenlace, se asemeja al del mayordomo. 
zo que separa la parte septentrional del Persiles de la meridional, que se regirá por el cronotopo del camino, que aproxima la fábula a los parámetros de la novela contemporánea.

La buena nueva que trae Sinibaldo a Renato y Eusebia y la mala razón que cuenta a Arnaldo provoca que el grupo conformado se fragmente en tres, según el rumbo que marcan los intereses particulares de cada uno. Rutilio, impresionado por la vida retirada de los franceses, opta por emular su ejemplo y se queda en la isla al cuidado de las ermitas; Renato, Eusebia y Sinibaldo se marchan a Francia, llevando consigo a Arnaldo, Mauricio, Transila y Ladislao; mientras que Periandro, Auristela y la familia de Antonio ponen rumbo a Lisboa.

En definitiva, esperamos haber tenido la facultad suficiente como para mostrar la magistral pericia con la que Cervantes dispone la materia narrativa del libro II del Persiles, su dominio total y absoluto del arte narrativo, por el que el episodio de Renato y Eusebia no solo es la secuencia narrativa en la que convergen las dos tramas paralelas que conforman el relato primario, sino que se convierte, merced a una tupida red de relaciones sintácticas y semánticas, en el engarce que cohesiona su composición toda en una armónica y equilibrada unidad, al mismo tiempo que allana el camino por el que continuará la acción ya en el libro III.

Recibido: 21-3-2006

Aceptado: 4-4-2008

\begin{abstract}
Resumen
En el presente trabajo nos hemos propuesto demostrar que el estilo del Persiles es soberbio, si lo entendemos como la confluencia de la expresión verbal en lo literario, donde el autor se convierte en el principal personaje de su obra. Para ello analizamos la técnica compositiva del libro II del Persiles, en torno al episodio de los ermitaños franceses Renato y Eusebia, dado que es la secuencia narrativa en la convergen los dos planos narrativos que lo configuran. Al mismo tiempo, ponemos el episodio en relación con el conjunto de la obra de Cervantes, en función de las múltiples relaciones temáticas y estructurales que establece con otros textos.
\end{abstract}

Palabras clave: Estilo. Épica en prosa. Episodio. Falsa acusación. Oposición corte-aldea. 
Title: «The virgin couple of Persiles»: the episode of Renato and Eusebia

\begin{abstract}
In the present work we have set out to demonstrate that the style of the Persiles is magnificent, if we understand it as the confluence of the verbal expression in the literary, where the author becomes the main character of his/her work. For this we have analysed the composition technique of book II of the Persiles, around the episode of the French hermits Renato and Eusebia, since this is the narrative sequence in which both narrative layers that form it come together. At the same time we place the episode in relation to Cervantes' set of work, on the basis of the multiple thematic and structural relations that it establishes with other texts.
\end{abstract}

Key words: Style. Epic in prose. Episode. False accusation. Opposition town-countryside. 